\title{
Risk Factors Associated with Vitamin D status among Children of an Urban and a Rural areas of Bangladesh
}

\author{
Saha $\mathrm{A}^{1 *}$, Shakur $\mathrm{MS}^{2}$, Laila $\mathrm{R}^{2}$, Shakur $\mathrm{S}^{3}$, Shomik $\mathrm{MS}^{4}$, Habib $\mathrm{RB}^{5}$ \\ ${ }^{1}$ Department of Paediatrics, Dhaka Medical College Hospital, Dhaka, Bangladesh; ${ }^{2}$ Department. of \\ Paediatrics, United Hospital Limited, Dhaka, Bangladesh; ${ }^{3}$ Uttara Adhunik Medical College, \\ Dhaka, Bangladesh; ${ }^{4}$ International Centre for Diarrhoeal Disease Research Bangladesh, Dhaka, \\ Bangladesh; ${ }^{5}$ Directorate General of Health Service, Dhaka, Bangladesh
}

\begin{abstract}
Background: Vitamin D deficiency is one of the most common micronutrient deficiency in children worldwide, even in Bangladesh. However, to date, the prevalence of vitamin D deficiency among children of different region of Bangladesh is less reported.

Objective: This study was conducted to assess vitamin D status of urban and rural Bangladeshi children including the risk factors associated with vitamin D deficiency are also evaluated.

Methods: A multi-centre (urban and rural based), cross sectional study was done from July 2016 to June 2017, using serum $25(\mathrm{OH})$ vitamin $\mathrm{D}_{3}$ as a marker of nutritional vitamin D status. Urban and rural children were taken from Paediatric Outpatient Department, United Hospital Limited. Dhaka and Medical Outpatient Department, Upazila Health Complex, Ghatail, Tangail respectively. Children of 1-10 years age attending OPD with mild undernutrition $(<-1 \mathrm{SD}$ z score $)$ and/or clinical features suggestive of vitamin $\mathrm{D}$ deficiency were included in the study.

Results: A total 150 children were studied with $102(68.0 \%)$ urban and $48(32.0 \%)$ rural children. Hypovitaminosis D $(25-\mathrm{OHD}<30 \mathrm{ng} / \mathrm{ml})$ was found in $75.0 \%$ of children. Hypovitaminosis D was found significantly more in urban children $(81.0 \%)$ compared to rural $(62.0 \%)$ children $(\mathrm{OR}=0.382,95 \% \mathrm{CI}$ : $0.177-0.822, p$ value $<0.05$ ). Inadequate exposure to sunlight was significantly associated with hypovitaminosis $\mathrm{D}$ compared to adequate sun exposure and it was about 2.5 times higher $(\mathrm{OR}=2.475$, $95 \%$ CI: $1.139-5.380, p$ value $<0.05$ ). No significant associations of vitamin D deficiency were detected with skin color of children, covering clothes of mother, exclusive breast feeding, limb pain and anthropometric status. Children of higher educated mother (above Secondary School Certificate) $(\mathrm{OR}=0.412,95 \%$ CI: 0.189-0.900) were more associated with vitamin D deficiency.

Conclusion: Vitamin D deficiency (VDD) is prevalent among Bangladeshi children, urban children being more vulnerable to VDD. Adoption of a screening programme for children of all age group and implementation of preventive strategies for VDD through public health policies are strongly recommended.
\end{abstract}

Keywords: Vitamin D, Serum 25(OH)D, Sun exposure, Hypovitaminosis D

\section{Introduction}

Vitamin D deficiency (VDD) is one of the most common micronutrient deficiencies of children and adult all over the world. ${ }^{1}$ It has re-emerged as a public health problem both in developing and developed countries (North America, Europe and UK) where it was thought to be eradicated.$^{2-4}$ The worldwide prevalence of vitamin D deficiency (VDD) is $30-50 \%$ among children and in tropical countries like India prevalence ranges from 70$100.0 \%$ among all age group..$^{5-6}$

Rickets which is the final stage of VDD represents only the tip of iceberg of huge vitamin D deficiency in children. ${ }^{7}$ However,

*Correspondence: Dr. Anamika Saha, Department of Paediatrics, Dhaka Medical College Hospital, Dhaka, Bangladesh; e-mail: ana007@saha@gmail.com; ORCID: 0000-0002-3689-8129 even apparently healthy looking children may have vitamin $\mathrm{D}$ deficiency with many health hazards consequences. It may present with growth failure, irritability, lethargy, muscle weakness, limb pain, hypocalcaemic seizure and repeated respiratory tract infection during infancy. ${ }^{8-9}$ Suboptimal vitamin D in school children in adolescent girl may have a role in determining bone mineral density and remain them at risk of osteoporosis and fracture when they become adult. ${ }^{10-11}$ Furthermore, it was found that. subclinical VDD may increase the risk of developing many chronic noncommunicable diseases in adult life like diabetes mellitus, autoimmune disease, ischaemic heart disease, hypertension, cancer, multiple sclerosis later in life. ${ }^{12-15}$ 
In Bangladesh, prevalence of vitamin D deficiency is frequently overlooked as it was assumed to be low risk due to cutaneous synthesis of vitamin $\mathrm{D}$ in exposure to abundant sunlight. Recently, it was found in one study that like elsewhere, vitamin D deficiency exist in high prevalent rate $(80.0 \%)$ in Bangladesh. ${ }^{16}$ Indoor based lifestyle and poor exposure to sunlight, air pollution and skin color, covering clothes of mother and child, educational status of mother are reported as important attributable factors for vitamin D deficiency. Exclusive breast feeding of infant also contributes to poor vitamin D status. ${ }^{17-20}$ However published data involving assessment of vitamin D status in children of different region of Bangladesh is scarce. Therefore, this study was undertaken to assess the vitamin D status in urban and rural Bangladeshi children. It was also evaluated the risk factors associated with vitamin D status in these children.

\section{Materials and Methods}

It was an observational type of cross-sectional study conducted in two centres of Bangladesh, one in urban metropolitan city of Dhaka and other in rural area. The urban centre was outpatient department of United Hospital Ltd a tertiary care based corporate hospital in Dhaka and the rural centre was in Ghatail Upazila (sub-district) Health Complex, Tangail-primary care-based hospital. It is $150 \mathrm{~km}$ away from Dhaka metropolitan city. This study was carried out from July 2016 to June 2017. Children of 1-10 years of age presenting with mild undernutrition (defined as weight for age (wt/age) or height for age (ht/age) or weight for height (wt/ht) <-1SD z score) and/or mild clinical features suggestive of vitamin $D$ deficiency (limb pain, muscle cramp, lethargy, irritability, bony deformity) were included in this study. Participants who were acutely ill, suffering from chronic disease, already on vitamin D supplementation and whose parents did not complete the questionnaire were excluded. A nonrandomized, convenience sampling technique was used. Sample size was calculated by using the following formula:

$$
\begin{aligned}
& n=\frac{Z^{2} p q}{d^{2}}=\frac{(1.96) 2 \times 50 x}{5^{2}}=\frac{3.84 \times 2500}{25}=\frac{9625}{25}=385 \\
& Z=1.96(\text { at } 5 \% \text { level, } 95 \% \mathrm{CI}) \\
& \mathrm{p}=50, \mathrm{q}=100-50=50, \mathrm{~d}=05
\end{aligned}
$$

Because of financial and time constraints it could not be enrolled whole sample which was a drawback of this study. Written consent was taken from the legal guardian of the children by explaining the purpose of the study. The study was approved by ethical committee of the United Hospital Ltd, Dhaka.

In depth interview was taken from parents or caregiver of the child by preparing a semistructured questionnaire which included age, gender, place of residence (urban or rural), exposure to sunlight, skin color, duration of exclusive breast feeding, maternal education, clothing pattern of mother. Sunlight exposure was defined sufficient if the children's skin were exposed to direct sunlight for more than $30 \mathrm{~min} / \mathrm{d}$ for several days in a week exposing head, face and forearms $\left(40 \%\right.$ of body surface area. ${ }^{21-22}$ Defined covering cloth of mother who used veil to cover their head. Weight and height were measure according to standard procedure and converted into $\mathrm{Z}$ score after standardizing with NCHS reference data. BMI was calculated by standard equation of weight in $\mathrm{kg} / \mathrm{h}^{2}$ in meter. All subjects were investigated for serum 25(OH)D level along with other investigations like serum calcium, alkaline phosphatase. Serum $25(\mathrm{OH}) \mathrm{D}_{3}$ was measured by chemiluminescent Immunoassay method widely used for routine laboratory test of vitamin D level. ${ }^{23}$ Children were considered to have vitamin $\mathrm{D}$ insufficiency and vitamin D deficiency if serum vitamin D level were between $20-29 \mathrm{ng} / \mathrm{ml}$ and $<20 \mathrm{ng} / \mathrm{ml}$ respectively. ${ }^{24}$ All reports were collected and analysed accordingly. A total of 284 children (164 urban and 120 from rural area) were selected for the study (figure 1).

Flowchart of sample collection

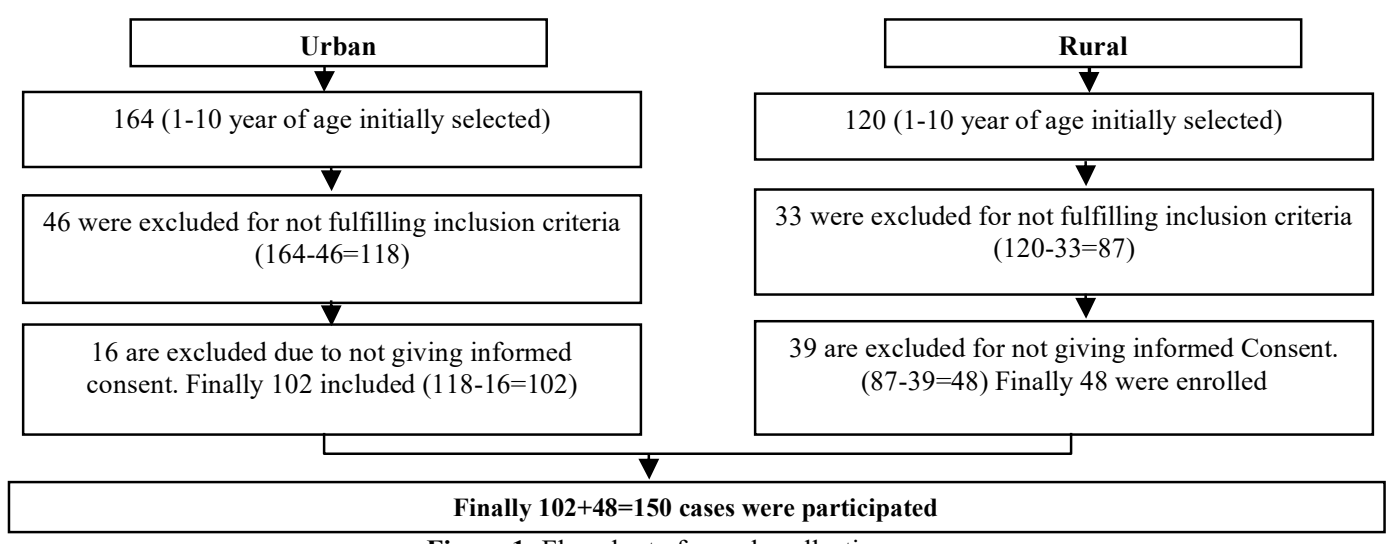

Figure 1: Flowchart of sample collection 
Statistical analyses: Data cleaning, validation and analysis were performed using Statistical Package for Social Science (SPSS), version 20. It was used odds ratio (OR) and 95\% confidence interval (CI) of OR to obtain strength of association between two parameters. Obtained odds ratio was considered significant if upper and lower confidence limit do not include 0 or 1 indicating significant $(<0.05)$ clinical association of the condition with a variable. It was also used ranks correlation coefficient (r) to obtain linear relationship between two parameters and it was considered statistically significant if $p$ value was $<0.05$.

\section{Results}

After fulfilling inclusion criteria total 150 children were included in the study. Among them 102 $(68.0 \%)$ children hailed from urban area and 48 $(32.0 \%)$ belonged to rural area. Majority of the children $(84 \%)$ were delivered at term with normal birth weight. Forty three $(29.0 \%)$ children's mother had education below Secondary School Certificate (SSC). Out of 150 children, only 48 $(32.0 \%)$ received adequate sunlight and 102 $(68.0 \%)$ children did not receive adequate exposure $(<30 \mathrm{~min} /$ day $)$ of sunlight. Among 102 urban children only $10(10.0 \%)$ children received adequate sunlight. On the contrary, out of 48 rural children $38(79.0 \%)$ received adequate sunlight. Fifty-seven percent of children received exclusive breast feeding up to 6 months. Ninety eight $(65.0 \%)$ children had dark color skin and $59.0 \%$ of mother of index children used covering clothes (veil). Baseline general characteristics of study population were also studied (table I).

Table I: General baseline and biochemical characteristics of study population $(n=150)$

\begin{tabular}{lcc}
\hline \multicolumn{1}{c}{ Variables } & $\begin{array}{c}\text { Total } \\
\text { Number } \\
(\mathbf{1 5 0 )}\end{array}$ & $\begin{array}{c}\text { Percentage } \\
\mathbf{( \% )}\end{array}$ \\
\hline Age & & \\
$12-59$ months & 87 & $58.0 \%$ \\
60-120 months & 63 & $42.0 \%$ \\
Gender & & \\
Boys & 82 & $54.7 \%$ \\
Girls & 68 & $45.3 \%$ \\
Residence & & \\
Urban & 102 & $68.0 \%$ \\
Rural & 48 & $32.0 \%$ \\
Gestational age & & \\
Term (>37 weeks gestation) & 126 & $84.0 \%$ \\
Preterm (<37 weeks & 24 & $16.0 \%$ \\
gestation) & & \\
Exclusive breast feeding & & \\
$<6$ months & 65 & $43.3 \%$ \\
$>$ 6 months & 85 & $56.7 \%$ \\
Maternal education status & & \\
Below Secondary School & 43 & $29.0 \%$ \\
Certificate (SSC) & & \\
Above Secondary School & 107 & \\
Certificate (SSC) & & \\
\hline
\end{tabular}

\begin{tabular}{lcc}
\hline $\begin{array}{l}\text { Exposure to sunlight (n- } \\
\text { 150) }\end{array}$ & \\
$<30 \mathrm{~min} /$ day & 102 & $68.0 \%$ \\
$>30 \mathrm{~min} /$ day & 48 & $32.0 \%$ \\
Covering of mother & & \\
Veiled mother & 88 & $58.66 \%$ \\
Non-Veiled mother & 62 & $41.33 \%$ \\
Skin color & & \\
Dark & 98 & $65.0 \%$ \\
Fair & 52 & $35.0 \%$ \\
\hline
\end{tabular}

Among features limb pain was found in 25 $(17.0 \%)$ cases and limb deformity in $8(5.0 \%)$ cases. Sixty five percent children were under weight (wt/age <-1SD), 54.0\% children were wasted (wt/ht $<-1 \mathrm{SD})$ and $54.0 \%$ children were stunted (ht/age <-1SD). Regarding biochemical features $35(26.0 \%)$ children presented with anaemia and $11.0 \%$ had iron deficiency. Baseline clinical and including biochemical characteristics of study population.

Table II: Clinical and biochemical characteristics of study population $(\mathrm{n}=150)$

\begin{tabular}{|c|c|c|}
\hline Variables & $\begin{array}{c}\text { Total } \\
\text { Number } \\
(150) \\
\end{array}$ & $\begin{array}{c}\text { Percentage } \\
(\%)\end{array}$ \\
\hline \multicolumn{3}{|l|}{ Limb pain } \\
\hline Yes & 25 & $17.0 \%$ \\
\hline No & 125 & $83.0 \%$ \\
\hline \multicolumn{3}{|l|}{ Limb deformity } \\
\hline Yes & 8 & $5.0 \%$ \\
\hline No & 142 & $95.0 \%$ \\
\hline \multicolumn{3}{|l|}{ Weight for age } \\
\hline Normal (>-1SD) & 52 & $35.0 \%$ \\
\hline Under weight (<-1SD) & 98 & $65.0 \%$ \\
\hline \multicolumn{3}{|l|}{ Weight for height } \\
\hline Normal (>-1SD) & 62 & $41.0 \%$ \\
\hline Wasted (<-1SD) & 88 & $54.0 \%$ \\
\hline \multicolumn{3}{|l|}{ Height for age } \\
\hline Normal (>-1SD) & 81 & $54.0 \%$ \\
\hline Stunted $(<-1 \mathrm{SD})$ & 69 & $46.0 \%$ \\
\hline \multicolumn{3}{|l|}{ Hypocalcaemia } \\
\hline Yes & 18 & $12.0 \%$ \\
\hline No & 132 & $88.0 \%$ \\
\hline \multicolumn{3}{|c|}{ Anaemia (Hb, 11gm/dl) (n-135) } \\
\hline Yes & 35 & $26.0 \%$ \\
\hline No & 100 & $74.0 \%$ \\
\hline \multicolumn{3}{|c|}{ Iron deficiency anaemia (n-135) } \\
\hline Present & 14 & $10.4 \%$ \\
\hline Absent & 121 & $89.6 \%$ \\
\hline
\end{tabular}

The majority of study population had hypovitaminosis $\mathrm{D}(\mathrm{n}=113,75.3 \%)$ and of them $39 \%$ had insufficient vitamin D (serum 25OHD between $20-29 \mathrm{ng} / \mathrm{ml}$ ) and $36.0 \%$ had vitamin $\mathrm{D}$ deficiency (serum $25 \mathrm{OHD},<20 \mathrm{ng} / \mathrm{ml}$ ). Significant vitamin D deficiency $(<15 \mathrm{ng} / \mathrm{ml})$ was found in $16.0 \%$ children (figure 1 ).

No significant association of hypovitaminosis D (serum vitamin $\mathrm{D}<30 \mathrm{ng} / \mathrm{ml}$ ) with age, gender and breast feeding was to be found (table III). 
However, children residing in urban area compared to rural area were significantly associated with hypovitaminosis D ( $\mathrm{OR}=0.382$, 95\% CI: 0.177-0.822).

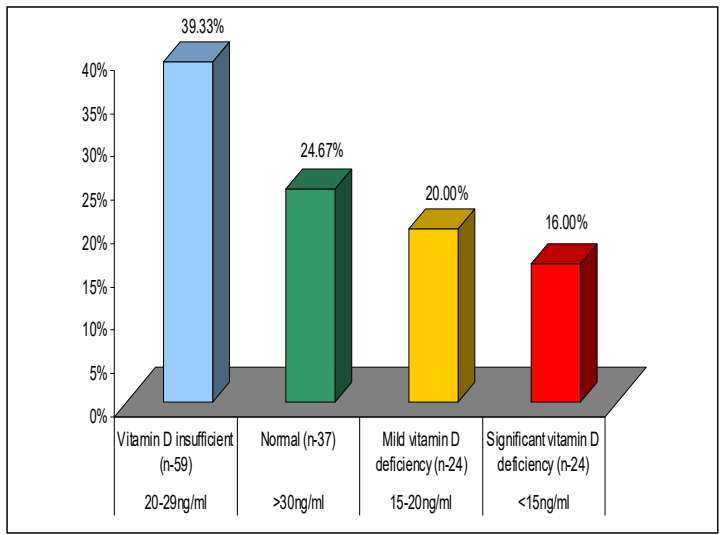

Figure 1: Study population according to vitamin D status

The statistically significant association of hypovitaminosis D (serum vitamin $\mathrm{D}<30 \mathrm{ng} / \mathrm{ml}$ ) with exposure to sunlight $(\mathrm{OR}=2.475,95 \% \mathrm{CI}$ : 1.139-5.380) was also found. Urban children and children with less sun exposure were significantly associated with hypovitaminosis D when the cutoff point of serum vitamin $\mathrm{D}$ was considered as $<20 \mathrm{ng} / \mathrm{ml} \quad(\mathrm{OR}=0.243, \quad 95 \% \quad \mathrm{CI}: \quad 0.104-0.572)$. There was no significant association of hypovitaminosis D was found with skin color, covering cloth of mother and limb pain (table III). Surprisingly children of higher maternal educational status (above SSC) were found more significantly associated $(\mathrm{OR}=0.412,95 \% \mathrm{CI}$ : $0.189-0.990$ ) with vitamin D deficiency compared to mother with low educational status (below SSC).

Although undernutrition was quite prevalent in study population however, there was no statistically significant association was to be found between hypovitaminosis $\mathrm{D}$ and anthropometric status. There was no association found between hypovitaminosis D and anaemia (table III).

Children residing in urban area are $62.0 \%$ more associated with hypovitaminosis D compared to rural children with serum vitamin $\mathrm{D}_{3}<30 \mathrm{ng} / \mathrm{ml}$, but they are more strongly $(76.0 \%)$ associated with hypovitaminosis $\mathrm{D}$ when the cutoff point of serum vitamin $\mathrm{D}_{3}$ was $<20 \mathrm{ng} / \mathrm{ml}$ (figure 2). Although statistically significant no such difference in magnitude of association of VDD was found to sun exposure to different cut of points of vitamin D status (figure 3).

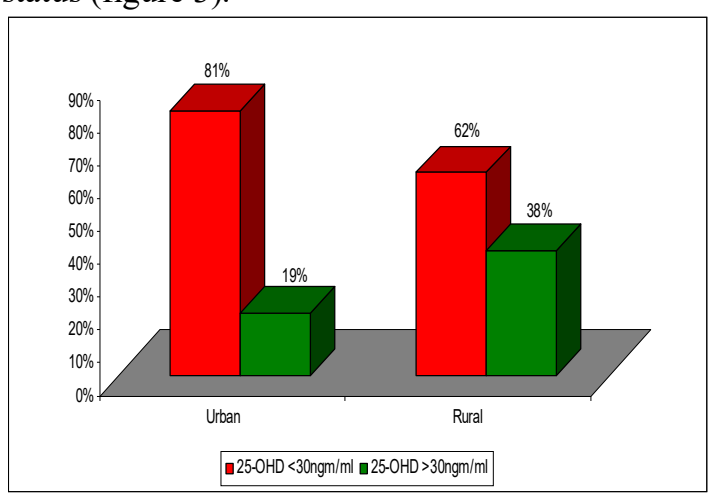

$\mathrm{OR}=0.382,95 \%$ CI: $0.177-0.822, p$ value 0.01

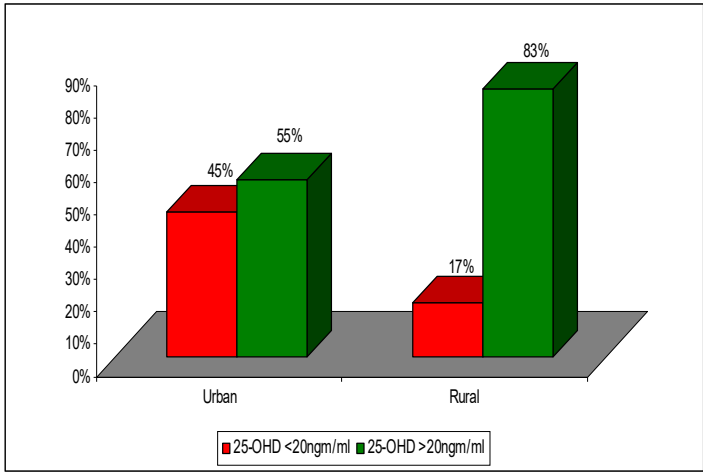

$\mathrm{OR}=0.243,95 \%$ CI: $0.104-0.572, p$ value 0.02

Figure 2: Type of residence as an univariate risk factor for hypovitaminosis $D$ at different magnitude $(<30 \mathrm{ng} / \mathrm{ml}$ and $<20 \mathrm{ng} / \mathrm{ml})$

Table III: Association of univariate risk factors with hypovitaminosis D $(25 \mathrm{OHD}<30 \mathrm{ngm} / \mathrm{ml})$

\begin{tabular}{|c|c|c|c|c|c|c|}
\hline Variables & $\begin{array}{c}\text { Children No (\%) } \\
n=150\end{array}$ & $\begin{array}{c}25-\mathrm{OHD}<30 \mathrm{ngm} / \mathrm{ml} \\
\text { No }(\%)\end{array}$ & $\begin{array}{c}25-\mathrm{OHD}>30 \mathrm{ngm} / \mathrm{ml} \\
\text { No }(\%)\end{array}$ & OR & $95 \% \mathrm{CI}$ & $P$ value \\
\hline \multicolumn{7}{|c|}{ ( } \\
\hline $12-59$ months & $87(58.0 \%)$ & $63(55.8 \%)$ & $24(64.9 \%)$ & \multirow{2}{*}{0.683} & \multirow{2}{*}{$0.316-1.474$} & \multirow[b]{2}{*}{0.33} \\
\hline $60-120$ months & $63(42.0 \%)$ & $50(44.2 \%)$ & $13(35.1 \%)$ & & & \\
\hline \multicolumn{7}{|l|}{ Gender } \\
\hline Boys & $82(54.7 \%)$ & $63(55.8 \%)$ & $19(51.4 \%)$ & \multirow[b]{2}{*}{1.194} & \multirow[b]{2}{*}{$0.567-2.512$} & \multirow[b]{2}{*}{0.64} \\
\hline Girls & $68(45.3 \%)$ & $50(44.2 \%)$ & $18(48.6 \%)$ & & & \\
\hline \multicolumn{7}{|l|}{ Residency } \\
\hline Urban & $102(68.0 \%)$ & $83(81 \%)$ & $19(19 \%)$ & \multirow[b]{2}{*}{0.382} & \multirow[b]{2}{*}{$0.177-0.822$} & \multirow[b]{2}{*}{$0.01 *$} \\
\hline Rural & $48(32.0 \%)$ & $30(62 \%)$ & $18(38 \%)$ & & & \\
\hline Sun exposure & & & & & & \\
\hline
\end{tabular}




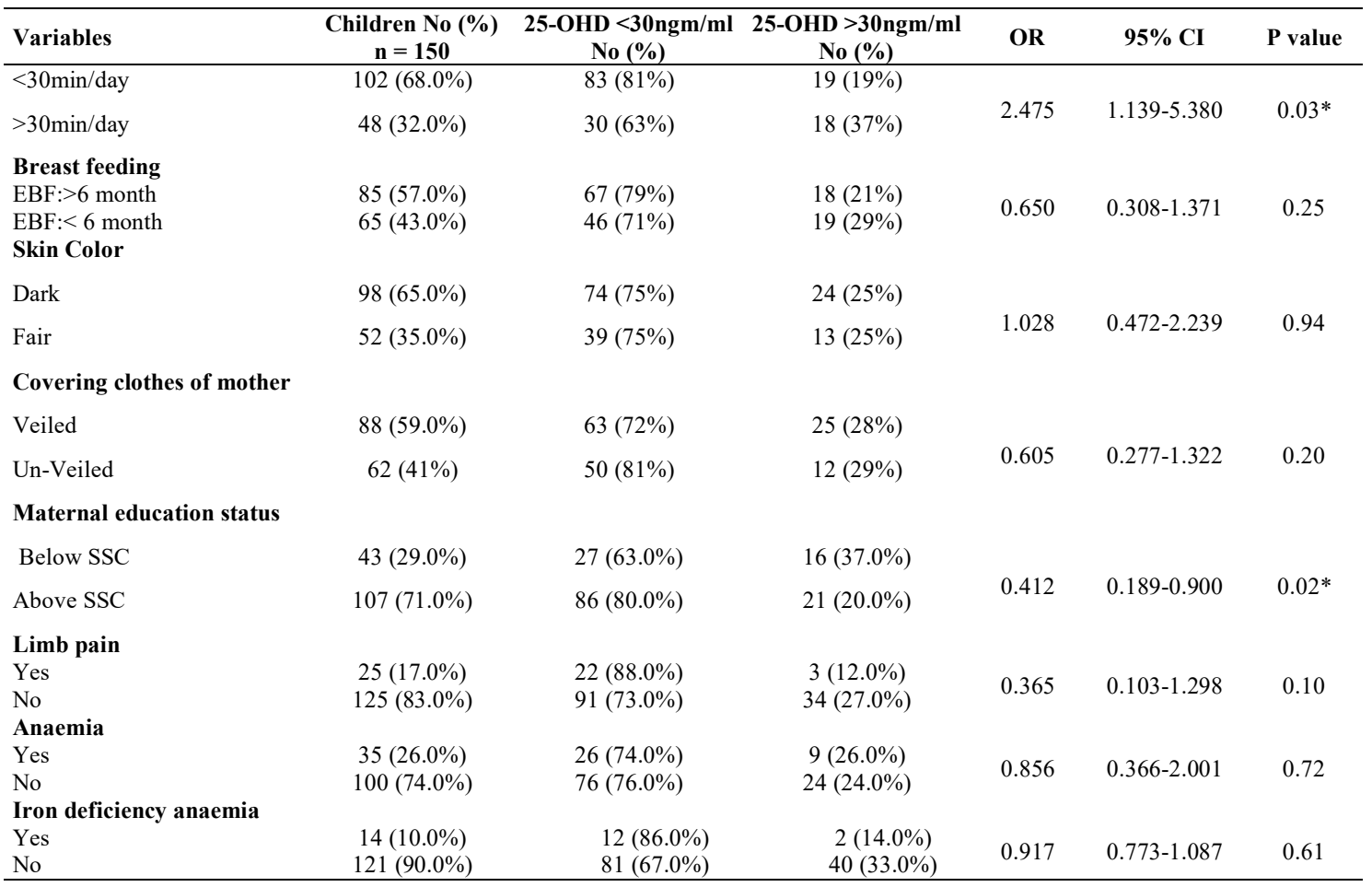

* Statistically significant if $\mathrm{p}$ value $<0.05$.

Weight for age, height for age has no significant linear relationship with vitamin D level was found (table IV). However, weight for height and BMI were statistically significant negative correlation with vitamin D status, which indicates overweight children were more vulnerable to develop vitamin D deficiency.

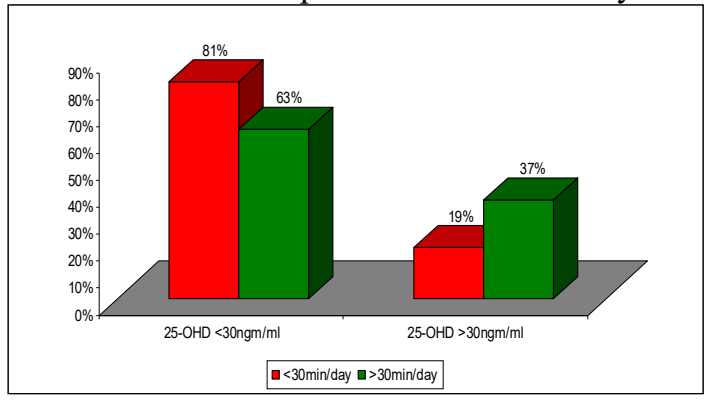

$\mathrm{OR}=2.475,95 \%$ CI: $1.139-5.380, \mathrm{P}$ value 0.03

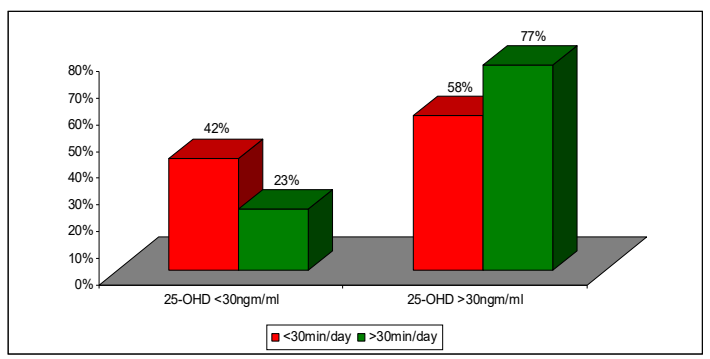

$\mathrm{OR}=2.451,95 \% \mathrm{C}: 1.124-5.347, p$ value 0.045

Figure 3: Exposure to sunlight as an univariate risk factor for hypovitaminosis D at different magnitude $(<30 \mathrm{ng} / \mathrm{ml}$ and $<20 \mathrm{ng} / \mathrm{ml}$ )
There was no significant relationship with serum calcium, alkaline phosphatase and haematological parameters with vitamin D status (figure 3).

Table IV: Vitamin D and anthropometric and biochemical variables

\begin{tabular}{lcc}
\hline \multicolumn{1}{c}{ Variables } & r & $\boldsymbol{p}$ value \\
\hline Weight /Age & -0.150 & 0.067 \\
Height /Age & +0.20 & 0.812 \\
Weight / Height & $-0.180^{*}$ & 0.027 \\
BMI & $-0.228^{*}$ & 0.005 \\
Calcium Level & -0.008 & 0.918 \\
Alkaline phosphatase & -0.061 & 0.493 \\
Haemoglobin & 0.030 & 0.754 \\
Ferritin & 0.068 & 0.490 \\
\hline
\end{tabular}

* Statistically significant if $p$ value $<0.05$.

\section{Discussion}

The result of the study revealed widely prevalent (75.0\%) hypovitaminosis D among Bangladeshi children, urban children being $62.0 \%$ were more associated with hypovitaminosis D compared to rural children.

The higher prevalence of hypovitaminosis $\mathrm{D}$ in Bangladeshi children could be generally explained by timing and duration of exposure to sunlight, geographical position, skin pigmentation and air pollution impairing synthesis of vitamin D endogenously. This study revealed that low 
vitamin D status was significantly more prevalent in urban children compared to rural children. More homebound lifestyle with involvement in indoor rather than outdoor games under sunlight, residing in poorly illuminated places probably are the main reasons for such situation. This finding is in line with the result of a study conducted by Howlader et al and Islam et al who showed indoor lifestyle and less sun exposure had significant impact on risk of vitamin D deficiency. ${ }^{21,25-26}$ Vitamin D deficiency (VDD) has also been reported despite presence of abundant sunlight in tropical countries like Pakistan, India, Kuwait and other Middle East countries due to less sun exposure which also supports our findings. ${ }^{27-29}$

VDD may affect bone growth and development of height. However, in this study no significant association was to be found between vitamin $\mathrm{D}$ and anthropometric status. On the contrary, significant negative correlation was found between vitamin D and weight for height and BMI, that is overweight children are more vulnerable to develop VDD. This is in agreement with other study where anthropometrically overweight or obese children had VDD. ${ }^{10,30-31}$

Many studies on women of South Asia and Middle East countries reported the negative influence of covering clothes (veiled woman) on vitamin D status. Clothing covering the head limit the sun exposure of skin and cutaneous synthesis of vitamin D irrespective of the intensity of ambient ultraviolet B. ${ }^{29,32-33}$ However, in this study it was not found any significant difference of serum 25OHD in children of veiled or nonveiled mothers was seen.

Dark skin individual are more associated with VDD compared to white individuals because of higher tendency to degrade already synthesized vitamin in the skin and difficulties in use of ultraviolet light. ${ }^{34}$ However, it was not found any significant difference of vitamin D status between those two groups.

Many studies reported that exclusive breastfed infants are vulnerable to VDD as there is less fetal transfer of maternal vitamin $\mathrm{D}$ and poor vitamin $\mathrm{D}$ content of breast milk..$^{17,35-36}$ In this study, it could not find any significant deficiency of vitamin D status in breastfed children and non-breastfed children for first 6 months of life. One of the reasons of low vitamin D status in Bangladeshi children can be explained by low physiological reserve of vitamin $\mathrm{D}$ in young infants which derived from mother.
One of the interesting finding of this study was significantly higher hypovitaminosis D in children of mother who had higher educational status (above SSC) in comparison to lower maternal education (below SSC level). Authors observed that the children of higher educated mother were found more over protective and engaged the children in homebound activities.

There are few limitations of this study. It could not be estimated the parathyroid hormone (PTH). Increased PTH activity associated with VDD indicates active VDD even asymptomatic and may have decreased bone mineral accumulation over time. Non random inclusion of children in this study was also a drawback.

\section{Conclusion}

This study brought on light over an underrated health issue that may have direct impact on child growth. It is strongly recommend to conduct an adequately powered population based long term cohort studies to evaluate the extent of vitamin D deficiency among the children. In addition, a national health policy needs to exist supporting the introduction of a screening programme on VDD and implementation of preventive measures such as encouraging people to adopt outdoor based lifestyle, fortification of milk and dairy products, vitamin D supplementation for the children of all age group to ensure proper growth and development.

\section{Acknowledgement}

We are thankful to Dr. Zahid Mahmud, Head of the Dept. Laboratory Medicine Dept. of United Hospital Ltd. and his team for helping us in proper collection of sample, preservation and estimation of serum vitamin $\mathrm{D}_{3}$ and other biochemical blood test. We are also grateful to the parents of the study children, nurses and staffs of United Hospital Ltd. and Upazilla Health Complex, Ghatail, Tangail.

\section{Conflict of interest: None.}

Funding: Maisha Health Care, North Jatrabari, Dhaka, Bangladesh.

Ethical approval: Ethical Committee of the United Hospital, Dhaka

Submitted: $16^{\text {th }}$ February, 2020

Final revision received: $23^{\text {th }}$ July, 2020

Accepted: $30^{\text {th }}$ July, 2020

Published: $1^{\text {st }}$ August, 2020 


\section{References}

1. Hilger J, Friedel A, Herr R et al. A systemic review of Vitamin D status in population worldwide. British Journal of Nutrition. 2014; 111:23-45.

DOI: $10.1017 / \mathrm{S} 000711451300184$

2. Antonucci R, Locci C, Clemente MG, Chicconi E, Antonucci L. Vitamin D deficiency in childhood: old lessons and current challenges. Journal of Pediatric Endocrinology \& Metabolism. 2018; $31: 247-60$

DOI:10.1515/jpem-2017-0391

3. Pettifor JM. Vitamin D \&/or calcium deficiency rickets in infants \& children: a global perspective study. Indian Journal of Medical Research. 2008;245-49.

PMID: 18497438

4. Gordon CM, Feldmen HA, Sinclair L, Williams AL, Kleinman PK et al. Prevalence of Vitamin D deficiency Among Healthy Infants and Toddlers. Archives of Pediatric \& Adolescent Medicine. 2008; 162: 505-12.

DOI: 10.1001/archpedi.162.6.505

5. Andiran N, Celik N, Akca H, Dogan G. Vitamin D Deficiency in Children and Adolescents. Journal of Clinical Research \& Pediatric Endocrinology. 2012;4:25-29.

DOI: $10.4274 /$ jcrpe. 574 .

6. Anitha A, Poovathinal SA, Vswambharan V, Thanseem I, Vasu MM. Cross sectional study reveals a high prevalence of vitamin D deficiency among healthy school children in central Kerala, India. International Journal Contemporary Pediatrics. 2019; 6:867-71.

DOI:10.18203/2349-3191.ijcp20190745

7. Greer FR. Issues in establishing vitamin D recommendations for infants and children. American Journal of Clinical Nutrition. 2004; $80: 1759$ s-62s.

DOI: $10.1093 / \mathrm{ajcn} / 80.6 .1759 \mathrm{~S}$

8. Shukla K, Sharma S, Gupta A et al .Current scenario of prevalence of vitamin D deficiency in ostensibly healthy Indian population. A hospital based retrospective study. Indian Journal Clinical Biochemistry. 2016;31:452-457.

DOI: $10.1007 / \mathrm{s} 12291-016-0552-2$

9. Wagner CL, Greer F. Prevention of Rickets and Vitamin D Deficiency in Infants, Children and Adolescent. Pediatrics. 2008; 122:1142-52.

DOI: $10.1542 /$ peds.2008-1862

10. Gowswami R, Mishra SK, Kochupillai N. Prevalence \& potential significance of vitamin D deficiency in Asian Indians. Indian Journal of Medical Research. 2008; 127:229-38.

PMID:18497436
11. Harinarayan CV, Ramalakshmi T, Prasad UV, Sudhakar D. Vitamin D status in Andhra Pradesh: A population based study. Indian Journal of Medical Research. 2008;127: 211-18.

PMID: 18497434

12. Holick MF, Chen TC. Vitamin D deficiency: A worldwide problem with health consequences. American Journal of Clinical Nutrition. 2008; $87: 1080$ S- 86 S.

DOI: $10.1093 / \mathrm{ajcn} / 87.4 .1080 \mathrm{~S}$

13. Akman AO, Turner L, Hasanoglu A, Ilhan M, Cayer B. Frequency of vitamin D insufficiency in healthy children between 1 and 16 year of age in Turkey. Pediatrics International. 2011;53:968-73.

DOI: 10.1111/j.1442-200X.2011.03486.x

14. Han SW, Kang HR, Kim HG, Kim JH, Uhm JH, Seo JY. Subclinical Vitamin D insufficiency in Korean School-aged Children. Pediatric Gastroenterology Hepatology Nutrition. 2013; $16: 254-60$.

DOI: $10.5223 /$ pghn.2013.16.4.254

15. Fischer PR, Thacher TD, Pettifor JM. Pediatric vitamin $\mathrm{D}$ and calcium nutrition in developing countries. Reviews in Endocrine and Metabolic Disorders. 2008; 9:181-92

DOI: 10.1007/s11154-008-9085-1

16. Zaman S, Hawlader MDH, Biswas A, Hasan M, Jahan $M$ et al. High Prevalence of Vitamin D Deficiency among Bangladesh Children: An Emerging Public Health Problem. Health. 2017; 9:1680-1688.

DOI:10.4236/health.2017.912123

17. Nair R, Masech A. Vitamin D: The "Sunshine vitamin". Journal OF Pharmacology \& Pharmacotherapeutics. 2012; 3:118-26.

DOI:10.4103/0976-500X.95506

18. Tolppanem AM, Fraser A, Fraser WB et al. Risk factors for variation in 25 Hydroxy vitamin D3 and D2 concentrations and vitamin D deficiency in children. The Journal of Clinical Endocrinology \& Metabolism. 2012; 97:1202-1210.

DOI: $10.1210 /$ jc.2011-2516

19. Mokhtar RR, Holick MF, Sampertegui F et al. Vitamin D status is associated with underweight and stunting in children aged 6-36 months residing in the Equadorian Andes.Public Health Nutrition. 2017; 21:1-12.

DOI:10.1017/S1368980017002816

20. Vith Streym S, Hojskov CS, Moller UK et al. Vitamin D content in human milk: a 9 month follow up study. American Journal of Clinical Nutrition. 2016; 103: 107-14

DOI: $10.3945 /$ ajcn.115.115105

21. Harinarayan CV, Holick MF, Prasad UV, Vani PS, Himabindu G. Vitamin D status and sun exposure in India. Dermato-Endocrinology. 2013; 5:130-141. 
DOI: $10.4161 /$ derm. 23873

22. Balasubramanian s, Ganesh R. Vitamin D deficiency in exclusively breast-fed infants. Indian Journal of Medical Research. 2008; 127:250-55 PMID:18497439

23. Arneson WL, Arneson DL. Current Methods for Routine Clinical Laboratory testing of Vitamin D Levels. Laboratory Medicine. 2013; 44:38-42.

DOI:10.1309/LMONQZQ27TIN7XFS

24. Holick MF. Vitamin D status: Measurement, Interpretation and Clinical Application. Annals of Epidemiology. 2009; 19:73-8.

DOI: 10.1016/j.annepidem.2007.12.001

25. Hawlader $\mathrm{MDH}$, Zaman S, Rahman M, Khan MNM, Hossain A, Ahsan GU. Determinants of vitamin D deficiency among Bangladeshi children: A hospital case-control study. Epidemiology Biostatistics and Public Health. 2019; 16:13186-89. DOI: $10.2427 / 13186$

26. Islam MZ, Lamberg-Allardt C, Karkkainen M, Outlia T, Salamatullah and Shamim AA. Vitamin D deficiency: a concern in premenopausal Bangladeshi women of two socio-economic groups in rural and urban region. European Journal of Clinical Nutrition. 2002; 56:51-56.

DOI: $10.1038 / \mathrm{sj} / \mathrm{ejcn} / 1601284$

27. Sachan A, Gupta R, Das V et al. High prevalence of vitamin D deficiency among pregnant women and their newborns in northern India. American Journal of Clinical Nutrition. 2005; 81:1060-64.

DOI: $10.1093 / a j c n / 81.5 .1060$

28. Al-Taiar A, Rahman A, Al-Sabah R, Shaban L, AlHabri A. Vitamin D status among adolescents in Kuwait: a cross-sectional study. BMJ Open. 2018;8: e021401.

DOI: 10.1136/bmjopen-2017-021401

29. Dawodu D and Wagner CL. Mother-child vitamin D deficiency: an international perspective. Archives of Disease in Childhood. 2007; 92:737-40.
DOI: 10.1136/adc.2007.122689

30. Gilbert-Diamond D, Baylin A, Mora-Plazas M, Marin C, Arsenault JE et al. Vitamin D deficiency and anthropometric indicators of adiposity in school-age children: A prospective study. American Journal of Clinical Nutrition 2010; 92:1446-51.

DOI: 10.3945/ajen.2010.29746

31. Gonzalez-Molcro I, Rojo-Martinez G, Morcillo S et al. Hypovitaminosis D and incidence of obesity: A prospective study. American Journal of Clinical Nutrition. 2013; 67:680-82.

DOI:10.1038/ejcn.2013.48

32. Çuhacı-Çakır B, Demirel F. Effects of seasonal variation and maternal clothing style on vitamin D levels of mothers and their infants. The Turkish Journal of Pediatrics. 2014; 56:475-81.

PMID: 26022581

33. Roth DE, Shah MR, Black RE and Baqui. Vitamin D status of infants in Northeastern Rural Bangladesh: Preliminary Observations and a Review of Potential Determinants. Journal of Health Population Nutrition. 2010; 28:458-69.

DOI: 10.3329/jhpn.v28i5.6154

34. Michie C, Bangalore S. Managing vitamin D deficiency in children. London Journal of Primary Care. 2010; 3:31-6.

DOI: 10.1080/17571472.2010.11493293

35. Razzak KKA, Ajilony MJA, Khoursheed AM, Obediate BA. Vitamin D deficiency among healthy infants and toddlers: A prospective study from Irbid, Jordan. Pediatrics International. 2011; 53:839-45.

DOI: 10.1111/j.1442-200X.2011.03388.

36. Jin HJ, Lee JH, Kim MK. The prevalence of vitamin D deficiency in iron-deficiency and normal children under the age 24 months. Blood Research. 2013; 48: 40-45.

DOI: $10.5045 / \mathrm{br} .2013 .48 .1 .40$ 